\title{
A Methodological Framework for Sustainable Office Building Renovation Using Green Building Rating Systems and Cost-Benefit Analysis
}

\author{
Nataša Šuman ${ }^{\circledR}$, Mojca Marinič and Milan Kuhta * \\ Faculty of Civil Engineering, Transportation Engineering and Architecture, University of Maribor, 2000 Maribor, \\ Slovenia; natasa.suman@um.si (N.Š.); mojca.marinic@student.um.si (M.M.) \\ * Correspondence: miso.kuhta@um.si; Tel.: +386-7078-7881
}

Received: 26 May 2020; Accepted: 27 July 2020; Published: 30 July 2020

check for updates

\begin{abstract}
Sustainable development is a priority for the future of our society. Sustainable development is of particular importance to the Architecture, Engineering, and Construction (AEC) industry, both for new buildings and for the renovation of existing buildings. Great potential for sustainable development lies in the renovation of existing office buildings. This paper introduces a new framework for identifying the best set of renovation strategies for existing office buildings. The framework applies selected green building rating system criteria and cost-effective sustainable renovation solutions based on cost-benefit analysis (CBA), and thus provides a novelty in decision-making support for the sustainable renovation of office buildings at an early-stage. The framework covers all necessary steps and activities including data collection, determination of the required level of renovation, selection of the green building rating system, identification of impact categories and criteria, and final evaluation and decision-making using CBA. The framework can be used in conjunction with different systems and according to different regional characteristics. The applicability of the addressing procedure is shown through a case study of a comprehensive renovation of an office building in the city of Maribor.
\end{abstract}

Keywords: sustainable construction; office buildings; building renovation; sustainable assessment; green building rating systems; BREEAM; cost-benefit analysis

\section{Introduction}

The sustainable development and implementation of projects based on the principles of sustainable development is becoming the present and certainly the future of our society. Sustainable development has been identified as a primary objective in the European Union (EU) and is fully represented in EU legislation, policy documents, and strategies such as the 2030 Agenda for Sustainable Development [1], Energy Performance of Buildings Directive (EPBD) [2], EPBD recast in 2010 [3], and transferred to the national strategy and guidelines of each EU Member State.

The implementation of sustainable development is particularly important for the AEC industry, as buildings are responsible for $40 \%$ of the EU's total energy consumption [3] and 36\% of the EU's total $\mathrm{CO}_{2}$ emissions [4]. Our review of the technical and scientific literature shows that sustainability thinking was particularly present in new public housing. However, a review of the European portal for energy efficiency in buildings_-BUILD UP [5] - suggests that sustainable development is now being applied to the renovation of existing buildings. Such orientations can also be found on the EU portal Executive Agency for Small and Medium-Sized Enterprises (SMEs)—EASME [6,7]. Furthermore, a "Secure, clean and efficient energy" work program has been launched at the EU level as part of Horizon 2020, which aims to increase the level of building renovation from the current $1.2 \%$ to $2-3 \%$ [8]. The importance of considering the renovation of existing buildings is also justified by the data from the 
Long-Term Strategy for Mobilizing Investments in the Energy Renovation of Buildings for Slovenia [9], which shows that within the fund of existing buildings $28 \%$ of non-residential buildings and $8 \%$ of them are office and commercial buildings.

The evaluation of sustainable construction projects is often carried out by benchmarks developed by green building rating systems. These rating systems include technical criteria for evaluating the degree of sustainability and the magnitude of the environmental impact of buildings and construction projects. In general, various green building rating systems have been developed worldwide, which form the basis of sustainable building evaluation and certification. The most commonly used systems are Leadership in Energy and Environmental Design (LEED) [10], Building Research Establishment Environmental Assessment Method (BREEAM) [11] and Deutsche Gesellschaft für Nachhaltiges Bauen (DGNB) [12], which are the most frequently cited in Elsevier's Scopus database [13-16]. LEED [10] and BREEAM [11] are also the oldest [13,14], and DGNB [12] is the most frequently used in Europe [14]. Currently in the EU, the reporting framework level(s) is emerging through the European Commission [17].

Recently, many studies have dealt with green building rating systems. Yuanyuan et al. [18] and Doan et al. [19] provided a systematic review, comparative analysis, and comparison of sustainable construction rating systems. Furthermore, studies [13,20-22] compared different green building rating systems according to their categories and criteria. Bernardi et al. [13] presented a detailed analysis and comparison of six of the most widely used and consolidated schemes of multi-criteria-based rating systems. Cole and Valdebenito [20] emphasized the importance of the increasing international use of the BREEAM and LEED rating systems and provide a detailed analysis of several projects assessed by these two systems. Zeinal and Huber [21] provided a general review and comparison of DGNB, LEED, and BREEAM, while Schwartz and Raslan [22] made comparisons between LEED and BREEAM for newly built residential buildings. In some cases, rating systems can also cover sustainable urban planning, as discussed by AlQahtany et al. [23] and Kaur and Garg [14], where the latter provided a comprehensive review of the most widely used green building rating systems.

Making decisions on the appropriate level of sustainable renovation of a building is based on the efficiency of the renovation measures. In practice, many decision-makers use traditional approaches to select the most effective renovation package based on an economic evaluation that determines which investment scenario can lead to the highest energy efficiency savings [24]. However, more sophisticated methodologies are also used such as decision-making (DM) techniques [24-30], Delphi, investment analysis [31,32], simulation-based sensitivity analyses [33], etc, while some studies deal with residential buildings [34] and some with commercial buildings [35,36]. Some studies [30,37-40] have dealt with the economic assessment of sustainable building renovation. In addition, evaluating the degree of sustainability of buildings using green building rating systems is also based on a quantitative multi-criteria assessment approach [10-12].

In the literature for the renovation of office buildings, several methods can be found as decision-making support tools for sustainability assessment such as quantitative multi-criteria or multi-attribute models [28,29]; some studies [27,35] have also focused on the optimization of energy demand for building operation with environmental characteristics and cost efficiency. Furthermore, Flourentzou et al. [36] developed an interactive decision support tool. Ma et al. [26] proposed an approach that took into account the trade-offs between energy and non-energy related factors and is implemented through key activities such as energy audits, building performance evaluation, economic analysis, and risk assessment. Juan et al. [27] developed a hybrid decision support system that included processes to assess the existing sustainability level and recommend an optimal set of renovation measures, taking into account the trade-offs between renovation costs, improved building quality, and environmental impact. GA and algorithm of the best-first search $\left(\mathrm{A}^{*}\right)$ were used to analyze the measures. In the search for the best renovation scenario, Rey [28] and Roulet et al. [29] examined the ELECTRE algorithm solution based on a multi-criteria calculation method, taking into account several criteria from three main areas of sustainability at the same time. Chidiac et al. [30] 
proposed a screening methodology to estimate energy consumption and determine the feasibility of energy-related renovation measures, which deals with calculating the payback period without considering the maintenance costs.

When deciding on the renovation of an office building today, it is important to consider sustainable and cost-effective solutions as this will help to make the right choice between the proposed renovation scenarios. Therefore, the hypothesis of the article is that it is possible to develop a framework as a powerful decision support tool for the renovation of office buildings, while at the same time, allowing the decision on the degree of sustainable renovation and cost-efficient measures to be made. When developing the tool, it was important to include accessible and extensible methods or criteria that do not require in-depth knowledge of decision-making methodologies based on algorithms and optimization models, as this allows easy decision-making at an early-stage of the project. A novelty in this paper is the proposal of a methodological procedural framework to identify the best renovation strategies for existing office buildings that can be used in the early stage of renovation projects. The framework has decision-making capabilities and includes tools for the sustainable application of selected criteria of the green building rating system and the upgrading of the sustainability rating with an economic valuation of cost-effective renovation solutions using CBA. The framework is unified to use one of the green building rating systems and their tools. The performance of the framework will be demonstrated in a case study based on a real case from practice. By implementing all of the steps and activities, it serves as a guide for a decision maker (the building expert) in the early-stage of planning sustainable building renovation measures and without in-depth knowledge of the individual assessment criteria. The results obtained will help the building owner to decide what to do with the building more easily: whether to invest in the renovation of the building, sell it, or demolish it and build a new one.

Our paper first gives a brief overview of the levels of renovation in terms of sustainability thinking. It then presents the legal basis and other documents for sustainable construction projects in the EU. The paper also contains the common characteristics for the most widely used green building rating systems BREEAM, LEED, DGNB [10-12] within the assessment system, impact categories, and assessment criteria used for the renovation of office buildings. The core of the article presents a new methodological framework for identifying the best set of renovation strategies for office buildings. The framework consists of four steps and represents a comprehensive flow of activities necessary for sustainable assessment using the green building rating system, and additionally, a CBA economic valuation, namely from data collection, selection of the green building rating system and its assessment system, impact categories and criteria, and the final sustainable evaluation through selected criteria and decision-making using CBA. The usability of the proposed procedure will be explained by means of a case study of a comprehensive renovation of an office building in the city of Maribor in Slovenia. At the end of the paper, conclusions and recommendations for future work are given.

\section{Sustainable Renovation of Buildings}

\subsection{Levels of Building Renovation}

The renovation of existing buildings has been addressed by the World Green Building Council [4], the Ministry of Infrastructure and the Ministry of Public Administration [9], Shah [40], and Yudelson [41]. When determining the level of renovation, the purpose of the building is first and foremost, the most important consideration. When determining the target level of renovation for residential buildings, energy efficiency and indoor comfort are important, while for non-residential buildings, the functional and operational status (e.g., working environment, frequency, and extent of emergency maintenance, risk of business failure, etc.) is important. Shah [40] defines five levels of renovation: "Light Touch/Refresh, Medium Intervention, Extensive Intervention, Comprehensive Refurbishment, and Demolition". The author notes that level 2 is most commonly used for office buildings, and refers to the whole building or to individual parts such as floors, installations, equipment, appliances, etc. 
All higher levels require consideration of the applicable space legislation, while a building permit should be obtained for levels 4 and 5 .

The final report of a comprehensive study of building energy renovation activities in the EU [42] provides the results on achieved renovation rates (defined as below threshold, light, medium, and deep renovations), energy savings, and investment costs for 28 EU Member States. In Slovenia, the largest share of investment for both residential and non-residential buildings was below the threshold.

In this study, sustainable renovation means a set of measures to improve the energy and environmental efficiency of the building in terms of sustainability. In Slovenia, different types of building renovation are addressed in the strategy [9]. Unfortunately, the vast majority of functional renovation measures that improve the function and overall condition (i.e., the modernization of an existing building) are not fully taken into account. As a result of sustainable renovation, the improvement of building structure, the renovation of building elements, and the increase of the usable floor space can be achieved by extending the building [43]. Furthermore, the overall benefits can also be reflected in social and environment effects (e.g., in the quality of living (air quality, thermal, visual and acoustic comfort), aesthetics, and others).

\subsection{Legislative Basis and Other Documents for Sustainable Construction Projects in the European Union}

The adoption of laws and directives that promote sustainable construction projects is not only important for the EU area, but sustainable development is a "global project". Therefore, continents and countries use different green building rating systems and levers to promote sustainable development across the AEC industry. In the following, we will limit ourselves to the adopted guidelines, standards, strategies, and directives in force at the EU level and valid documents specific to Slovenia in the case study.

In the EU, the most important documents are the 2030 Agenda for Sustainable Development [1], Energy Performance of Buildings Directive [2], EPBD recast in 2010 [3], and Directive on the promotion of the use of energy from renewable sources [44]. Directives are the starting point and basis for national legislation of the EU Member States.

Various programs have been implemented or are under way in the European area. For example, two programs have been introduced within the 7th Framework Program for Research and Technological Development (FP7), namely SuPerBuildings [45] and Open House [46]. Furthermore, the BUILD UPON project [47] was carried out as part of Horizon 2020 with the following objectives: promote energy-efficient renovation of residential and commercial buildings; develop a national renovation strategy; and share knowledge and best practices. Currently, Level(s) [17] is in the test phase from 2018 to 2020, with the objectives of defining sustainable construction criteria, certifying buildings, and supporting the decision-making process for the implementation of sustainable construction. It is expected to provide robust indicators and guidelines at a general level.

With a view to promoting sustainable construction, the Energy Balance for each EU Member State is also important. It provides information on (i) the total annual consumption of each energy source, and (ii) final energy consumption separately for six groups. As an example, the data of the Energy Balance of the Republic of Slovenia [48] for 2019 are cited for the group "Other consumption" where the annual final energy consumption of total consumption was $11.6 \%$ in $2017,10.6 \%$ in 2018 , and $10.6 \%$ in 2019, while the forecast for 2020 was $10.5 \%$. This is a moderate reduction in consumption, which must also be further reduced by the energy renovation of buildings.

\subsection{Strategic Documents and Legislation for Sustainable Construction Projects in Slovenia}

In Slovenia, measures to improve energy efficiency are laid down in the Energy Act [49], which lays down the principles of energy policy and energy efficiency. The Energy Act defines strategic development documents such as the Energy Concept of Slovenia [50] (in preparation), the Action Plan for Energy Efficiency by 2020 [51], and Long-Term Strategy for Mobilizing Investments in the Energy Renovation of Buildings [9]. Statutes have also been adopted such as Rules on the efficient 
use of energy in buildings with a technical guideline [52] and Technical Guidelines—Efficient Use of Energy [53].

In this respect, the strategy [9] offers an overview and potential for the renovation of the national building stock and provides measures for the energy renovation of the building. Among the most common are measures on building envelopes, heating, ventilation and air-conditioning systems, the use of hot water and electricity, and in the production of electricity. The strategy identifies the levels of energy renovation as a single-measure, partial renovation, comprehensive energy renovations, and nearly zero-energy buildings (nZEB).

\section{Materials and Methods}

\subsection{Common Characteristics of the Green Building Rating Systems for Renovation}

When implementing sustainable construction projects, various green building rating systems are used in practice, which offer the possibility of verifying correctness and effectiveness of the planned renovation measures. In general, rating systems are drawn up separately for each type of building, as their application is required to demonstrate the uniform level of environmental friendliness, economic efficiency, and social compatibility of the planned renovations. Various green building rating systems have been developed worldwide such as BREEAM [54], HQE [55], LEED [56]), CASBEE [57], GREEN STAR [58], DGNB [59], and Level(s) [17] (in progress). All rating systems differ in terminology, structure, and performance assessment procedures [60]. What they all have in common, however, is that they all refer to different environmental impacts and are divided into meaningfully completed assessment schemes with the appropriate technical standard that best suits the project. It is important to note that user manuals are produced for different types of buildings, neighborhoods, urban design, etc. Well defined assessment criteria are formulated for a intervention at the lowest level, both for a new and an existing building. The criteria are evaluated by scoring and serves as a basis for a sustainable assessment and the award of certificate. All criteria together are called the assessment system, which is specific to individual building types. However, each assessment system is divided into several impact categories that differ in description, content, and number. Therefore, the sum of the points scored by each criteria (at the level of scoring) gives the answer of the expected certificate performance. Figure 1 shows the proposed general component names that have been merged from different green building rating systems, and therefore the names have been unified for all rating systems.

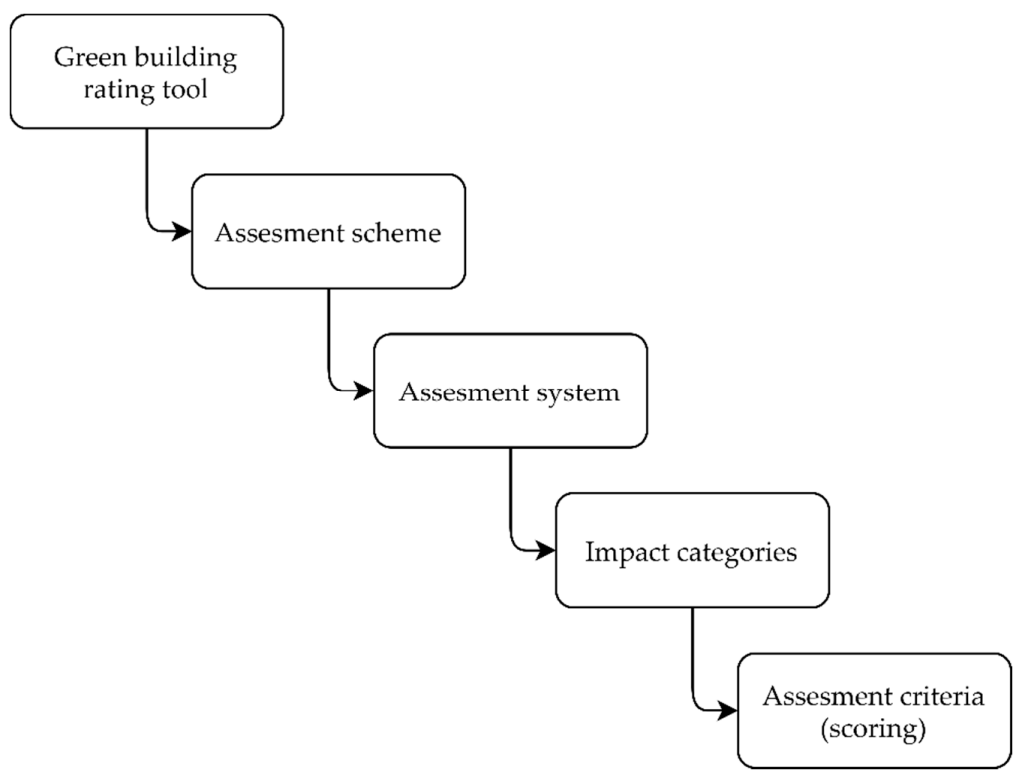

Figure 1. Unified components of a green building rating system. 


\subsection{Methodological Framework for the Sustainable Assessment of the Renovation of Office Buildings}

The renovation of existing office buildings is associated with high financial investment, while renovation trends focus on sustainable renovation. It is therefore important that the owner or investor decides on the concept of renovation based on a systematic analysis and thus on the future environmental, social, and economic impacts. For this reason, it is useful to establish a systematic procedure to support the identification, treatment, and analysis of planned improvement measures. Figure 2 presents our new methodological framework for identifying the best set of proposed renovation strategies, which applies to office buildings and comprises four steps.

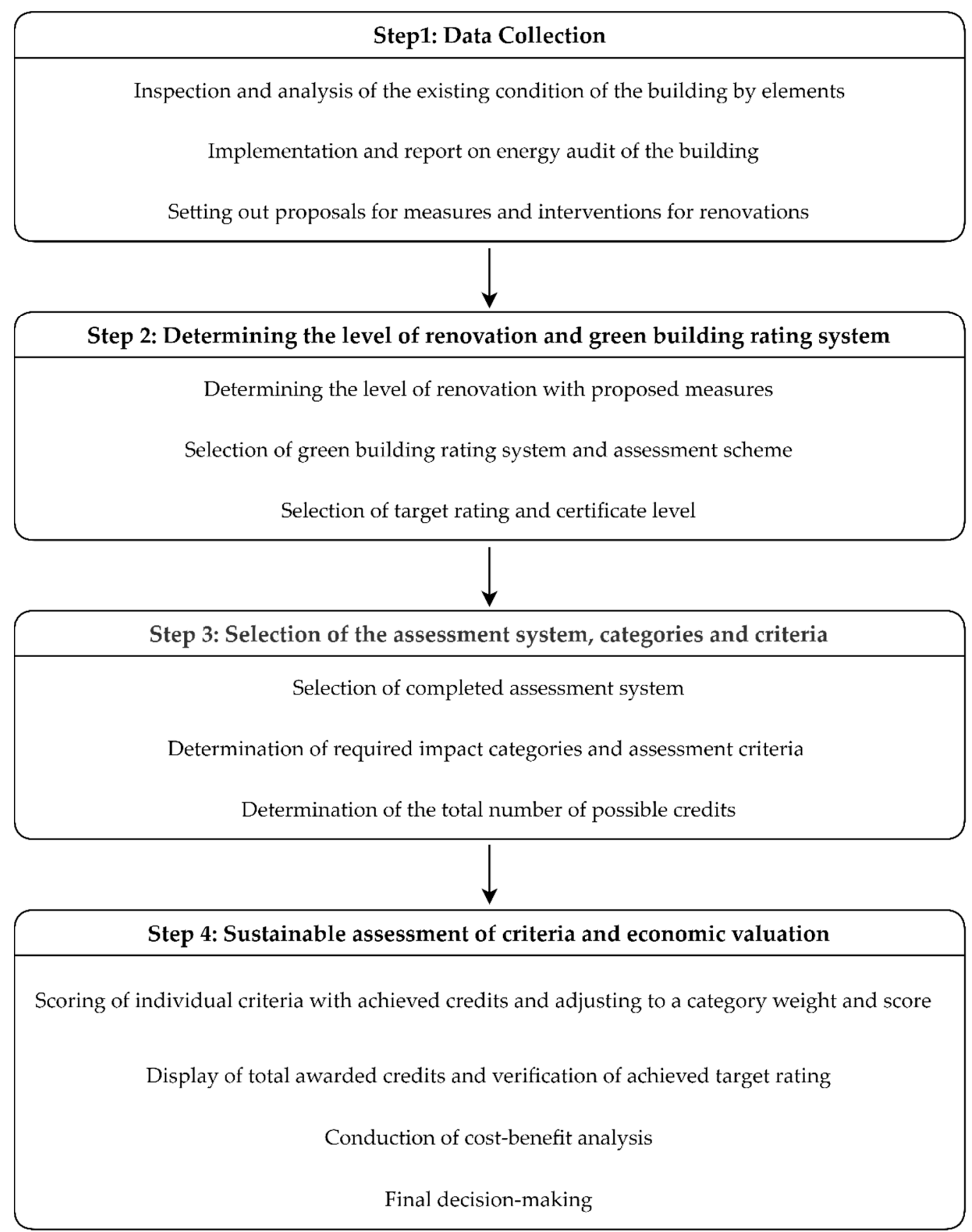

Figure 2. A methodological framework for sustainable office building renovation using a green building rating system and cost-benefit analysis. 
The evaluation of the proposed renovation strategies, either comprehensive or step-by-step, starts with the investor's decision to carry out the renovation. In general, an interdisciplinary project team should be organized by hiring a consultant who is familiar with the content and assessment tools of green building rating systems. The project team therefore collects data in Step 1. First, the existing building must be inspected, and an analysis of the existing condition should be carried out separately for each building element. In parallel, an energy audit is carried out, which primarily provides a detailed overview of the building's energy consumption and can also include data on annual energy costs, the survey and analysis of the actual structural condition of the building, and its energy systems as well as proposals for the measures for complete energy-related renovation and feasibility analysis. Based on analysis and reports, the team recognizes the renovation needs and develops proposals for renovation measures and interventions.

In Step 2, the required level of renovation should be determined including appropriate measures for energy saving and functional improvement. This is followed by the selection of the green building rating system and the corresponding assessment scheme. Each owner has their own priorities for the renovation, so the owner selects the most appropriate normative assessment scheme. However, regional characteristics and the actual usability of the system for a particular building location can also influence the choice of the rating system. In general, any green building rating system should allow for an assessment of the degree of sustainability. Depending on the green building rating system chosen, the target rating and certificate level (see Table 2) must also be selected. Furthermore, after examination and scoring of the assessment criteria (carried out in Step 4), the team can identify additional measures that could include various functional renovations.

In Step 3, the team selects a completed assessment system for the chosen green building rating system that is required to achieve the target certificate. Based on the selected renovation solutions, the required impact categories and assessment criteria as well as the total number of possible credits are determined. Impact categories combine technical criteria for evaluating sustainability, usually divided into the main categories of environmental, economic, and social aspects. Different assessment criteria are defined for each impact category and the maximum number of credits is determined for each criteria. All this is defined by the guidelines and technical standards that apply to each green building rating system.

In the final Step 4, the team's experts carry out a sustainable evaluation and an economic CBA evaluation. The scope of the sustainable evaluation includes the iterative method for rating the building's degree of sustainability. The analysis is quantitative; the technical criteria are so-called assessment criteria that are weighted. The weighting of criteria replaces the numerical processes and implies a priority of the owner over the more important criteria for sustainable building renovation [61]. Therefore, scoring and rating are performed by individual criteria for each renovation measure using standardized tools or calculators as defined or recommended by technical standards. In this way, each measure is assigned the number of credits awarded and display the proportion (in \%) of "available credits", which is then adjusted to the weighting according to the level of category. This results in a category score and the result of the total score. In addition, the total score is compared with the target rating level, which checks whether the minimum standard for achieving the selected certificate is achieved. In doing so, a sustainable evaluation includes the evaluation of the technical criteria within three main categories and anticipates Life Cycle Costs in the determination of the economic category. In addition, the scope of economic evaluation provides the calculation of the cost-effectiveness of the proposed renovation strategies through the implementation of the CBA, which is the next sub-step. Such an evaluation provides a decision-maker with an overview of the assessment of the financial benefits as well as an evaluation of other multiple project benefits. Both the sustainable evaluation and economic evaluations thus form the basis for a final decision.

To support the implementation of Step 3, the characteristics of LEED, BREEAM, and DGNB with a focus on office buildings are listed below. To support the implementation of Step 4, the basics for CBA are also given. 


\subsection{Characteristics of LEED, BREEAM, and DGNB for the Renovation of Existing Buildings}

There are various schemes for the sustainable evaluation of existing office building renovations, namely the schemes LEED Operations and Maintenance [56], BREEAM Refurbishment and Fit-Out [54], and DGNB Existing Buildings and Renovation [59]. The LEED Operations and Maintenance scheme provides an opportunity for different types of existing buildings to pay special attention to building operation by supporting whole buildings and interiors. The scheme does not specifically define office buildings. The BREEAM Refurbishment and Fit Out scheme can be used for most types of existing buildings including residential, non-residential, office, and heritage buildings [54]. The DGNB Existing Buildings and Renovation scheme offers various applications for the renovation projects applicable to residential and non-residential buildings, in which offices are also specifically defined [59].

Table 1 gives an overview of selected green building rating systems for the renovation of existing buildings. A detailed overview of the names of the relevant assessments schemes, their assessment system, and the rating and certification level are presented here according to the respective technical standard, although in practice they are constantly updated.

Table 1. An overview of selected green building rating systems (summarized in $[54,56,59]$ ).

\begin{tabular}{|c|c|c|c|}
\hline & LEED & BREEAM & DGNB \\
\hline Scheme & $\begin{array}{c}\text { Operations } \\
\text { and Maintenance }\end{array}$ & $\begin{array}{l}\text { Refurbishment } \\
\text { and Fit-out }\end{array}$ & $\begin{array}{l}\text { Existing Buildings } \\
\text { and Renovation }\end{array}$ \\
\hline Assessment system & $\begin{array}{c}\text { New construction and } \\
\text { major renovation } \\
\text { Schools } \\
\text { Retail } \\
\text { Hospitality } \\
\text { Data centers } \\
\text { Warehouses and } \\
\text { Distribution centers }\end{array}$ & $\begin{array}{c}\text { Residential buildings } \\
\text { Commercial buildings } \\
\text { Retail } \\
\text { Offices } \\
\text { Hotels } \\
\text { Industrial buildings } \\
\text { Public buildings } \\
\text { Education buildings } \\
\text { Healthcare } \\
\text { Residential institutions } \\
\text { Non-standard building } \\
\text { types } \\
\text { Heritage buildings }\end{array}$ & $\begin{array}{c}\text { Office and } \\
\text { administration buildings } \\
\text { Educational buildings } \\
\text { Residential buildings } \\
\text { Consumer market } \\
\text { buildings } \\
\text { Shopping center } \\
\text { buildings } \\
\text { Department stores } \\
\text { Logistic buildings } \\
\text { Production buildings } \\
\text { Hotel buildings }\end{array}$ \\
\hline $\begin{array}{c}\text { Rating and } \\
\text { certificate level }\end{array}$ & $\begin{array}{l}\text { Platinum } \geq 80 \text { points } \\
\text { Gold } 60-79 \text { points } \\
\text { Silver } 50-59 \text { points } \\
\text { Certified } 40-49 \text { points }\end{array}$ & $\begin{array}{c}\text { Outstanding } \geq 85 \% \\
\text { Excellent } \geq 70 \% \\
\text { Very good } \geq 55 \% \\
\text { Good } \geq 45 \% \\
\text { Pass } \geq 30 \% \\
\text { Unclassified }<30 \%\end{array}$ & $\begin{array}{c}\text { Platinum } \geq 80 \% \\
\text { Gold } \geq 65 \% \\
\text { Silver } \geq 50 \% \\
\text { Bronze } \geq 35 \%\end{array}$ \\
\hline
\end{tabular}

Each selected rating system has certain impact categories and assessment criteria (scoring). Table 2 shows in detail the impact categories of selected green building rating systems and the allocation of credits for the renovation of office buildings. For each category, the possible total value of credits received is indicated, which applies to the maximum standard. The categories are ranked from those with the most credits to those with the lowest possible.

Table 2 shows that the individual assessment scheme does not have the same number of impact categories, and consequently a different value of the total credits. Furthermore, the categories have different names, content, and weights in determining the final scoring, which prevents a comparison of the rating systems. 
Table 2. Review of impact categories and scoring for the renovation of office buildings (summarized in $[54,56,59])$.

\begin{tabular}{|c|c|}
\hline \multicolumn{2}{|l|}{ LEED } \\
\hline Operations and Maintenance & cr. \\
\hline EA-Energy and Atmosphere & 35 \\
\hline EQ-Indoor Environmental Quality & 22 \\
\hline WE-Water Efficiency & 15 \\
\hline LT-Location and Transportation & 14 \\
\hline MR—Materials and Resources & 9 \\
\hline SS—Sustainable Sites & 4 \\
\hline IN-Innovation & 1 \\
\hline Total possible credits & 100 \\
\hline \multicolumn{2}{|l|}{ BREEAM } \\
\hline Refurbishment and Fit-out & cr. \\
\hline Ene-Energy & 35 \\
\hline Hea-Health and wellbeing & 22 \\
\hline Man-Management & 21 \\
\hline Pol-Pollution & 14 \\
\hline Mat-Materials & 13 \\
\hline Wst-Waste & 13 \\
\hline Tra-Transport & 11 \\
\hline Inn-Innovation & 10 \\
\hline Wat-Water & 9 \\
\hline Leo-Land use and ecology & 4 \\
\hline Total possible credits & 152 \\
\hline \multicolumn{2}{|l|}{ DGNB } \\
\hline Existing Buildings and Renovation & cr. \\
\hline SOC-Sociocultural-functional quality & 19 \\
\hline ENV_Ecological quality & 15 \\
\hline PRO_Process quality & 12 \\
\hline ECO_Economical quality & 6 \\
\hline TEC_-Technical quality & 2 \\
\hline Total possible credits & 54 \\
\hline
\end{tabular}

\subsection{Cost-Benefit Analysis}

When deciding on the measures to be taken to renovate the energy efficiency of existing buildings, cost efficiency is the main consideration for the investor. Consequently, the assessment of the economic justification can be carried out with the help of the cost-benefit analysis (CBA). The CBA is a systematic approach, normally used in project investment to estimate the value of the expected benefits compared to the costs of a project. When deciding on appropriate energy and non-energy related measures for the sustainable renovation of existing buildings, investors or owners need the following key information: the impact of the quality improvement of the renovation measure on the project costs, the increase in market price or tenant rates, the increase in the space occupancy rate, the savings in energy and other operating and maintenance costs, and the return on investment in the measures. Nevertheless, when evaluating the impact of sustainable renovation, not only the economic effect, but also the environmental and social aspects (e.g., improving comfort in the building) should be considered, but experience to data suggests that the economic outcome is the most important.

The CBA can focus only on costs (financial analysis). However, sustainable building renovation projects should also consider other project benefits such as increased building values or tenant rates, which is why the benefit assessment is introduced as a so-called economic analysis. Accordingly, Bleyl et al. [38] identified multiple project benefits (MPB) for the energy-efficient renovation of office buildings such as increased rents, real estate values, and (employee) productivity as well as savings in 
maintenance costs and $\mathrm{CO}_{2}$. The authors also provide the approaches to the monetization MPB and their monetary values. In the economic analysis, cash flow not only takes into account future energy cost savings, but also other economic benefits that can add significant value for investment decision-makers.

In general, several methods can be used for CBA analysis (e.g., discounted cash flow, annuity method, dynamic payback period, and net present value (NPV). The most used method is the NPV method, which takes into account all annual costs and all cost savings at the current net present value using the cumulative discount rates. The project is economically viable if the NPVs of the savings and costs are positive.

The assessment of the economic impact of building renovation projects is most frequently carried out for energy-related measures (i.e., measures on the thermal envelope, HVAC, and supply systems. Different solutions are prepared and a comprehensive energy analysis of the building should be carried out. Next, an LCC analysis is performed for the chosen solutions in a selected period of time, considering the life cycle costs of the measures [39]. In addition, to determine the eligibility of investments, an economic evaluation of the measures is carried out (e.g., by means of a CBA analysis). This involves calculating the net present value of renovation solutions in terms of pure cost (i.e., for financial analysis) using Equation (1), and in terms of other MPB (i.e., for economic analysis) using Equation (2).

$$
\begin{gathered}
\mathrm{NPV}_{0, \mathrm{f}}=-I_{0}+\sum_{t=1}^{t=n} \frac{S_{n}-C_{n}}{q^{t}}+\frac{\mathrm{RV}_{n}}{q^{t}} \\
\mathrm{NPV}_{0, \mathrm{e}}=-I_{0}+\sum_{t=1}^{t=n} \frac{S_{n}-C_{n}}{q^{t}}+\frac{\mathrm{RV}_{n}}{q^{t}}+\frac{\mathrm{MPB}_{t}}{q^{t}}
\end{gathered}
$$

where $\mathrm{NPV}_{0, \mathrm{f}}$ is the net present value for the financial analysis; $\mathrm{NPV}_{0, \mathrm{e}}$ is the net present value for the economic analysis; $I_{0}$ is the investment; $S_{n}$ is the energy saving for year $\mathrm{t} ; C_{n}$ maintenance cost for year $t ; q$ is the discount factor, $q=1+i / 100 ; i$ interest rate in $\% / \mathrm{a} ; t$ observation period in years; $n$ calculated operating lifetime period in years; $\mathrm{RV}_{n}$ residual value in year $n$; and $\mathrm{MPB}_{t}$ is the multiple project benefit for year $t$.

\subsection{Description of the Current Condition of the Office Building in the Case Study}

The building is located in the city center of Maribor. It was designed and built from 1976 to 1980 and is a representative office building of the time. It has 12 floors (two basements, ground floor, and nine floors), two passenger and one goods lift, and three staircases. The total net floor area (NFA) is $8552.0 \mathrm{~m}^{2}$, the total net heated floor area $\left(\mathrm{A}_{\mathrm{NHF}}\right)$ is $6440.0 \mathrm{~m}^{2}$, and the height is $34.8 \mathrm{~m} \mathrm{[62].}$

The load-bearing structure of the building is made of reinforced concrete (foundations, elevator core, skeleton structure (slabs, beams, columns) and staircases). The partition walls are made of Porolit brick, while the partition walls between the offices are dry-erected. The façade mostly consists of self-supporting cast aluminum elements with inlaid thermal insulation inserted (Figure 3). The windows have an aluminum frame and are glazed with thermal insulation glass. External blinds were installed subsequently. The roof is a classic flat roof with gravel; the roofing covering was replaced in 1994. The completion of the interior spaces was done with all elements as visible concrete, only some of them are painted. The finished floors are fitted with different materials (natural stone, carpets, rubber floors, parquet floors, ceramics, etc.). The ceilings were designed as a lowered ceiling, partly as lamella and partly as dry ceilings [62]. 


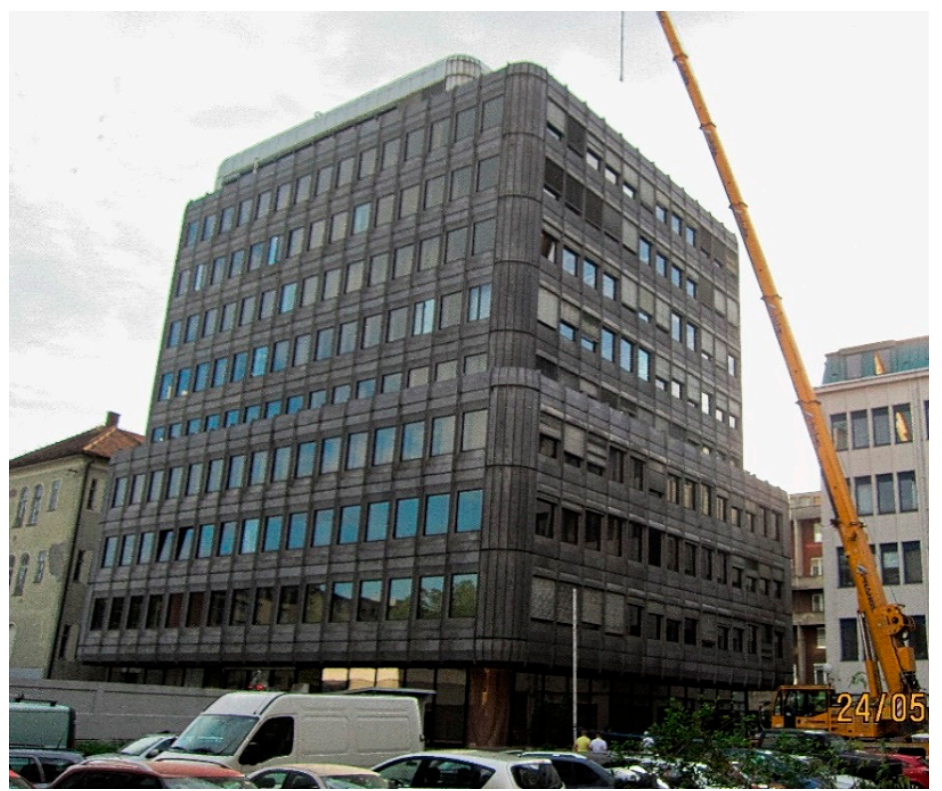

(a)

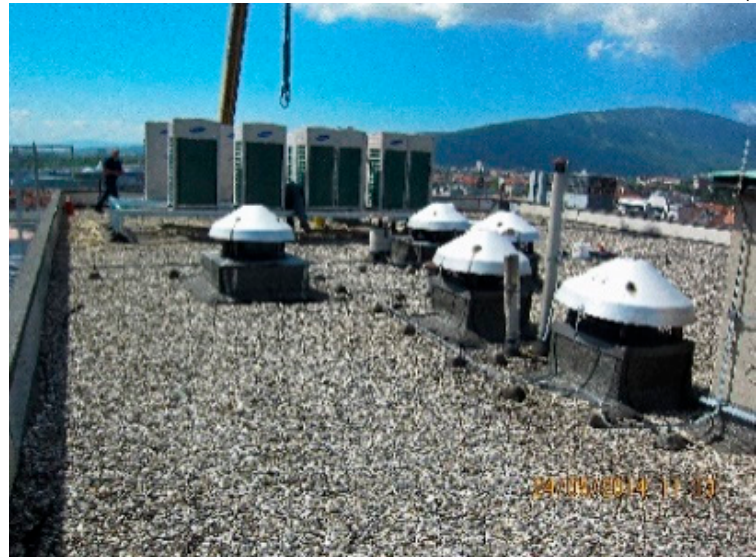

(b)

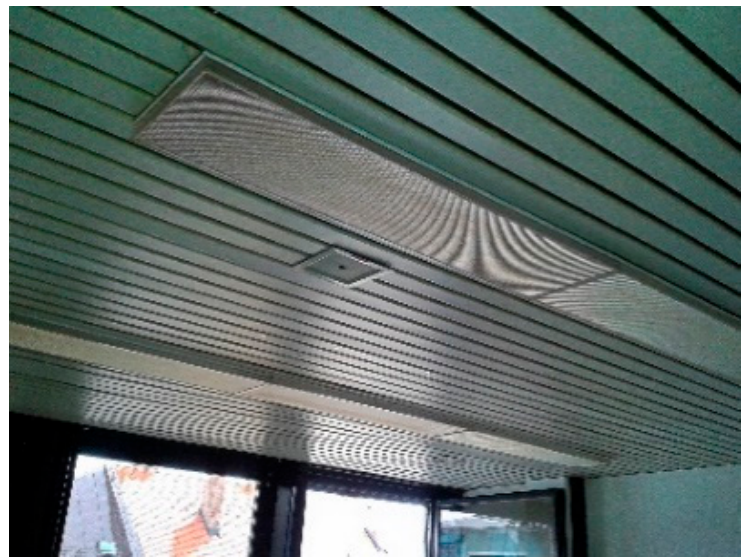

(c)

Figure 3. Office building: North and East—with exterior shades—façade (a); roof (b); lamellar lowered ceiling (c). Source: Marinič [62].

The building is connected to the municipal infrastructure (water supply, sewerage, electricity, natural gas, internet). It has its own boiler room, and a forced and natural ventilation and cooling system. The building is heated by a central radiator; the energy source for heating is natural gas. In 2014, the office lighting was replaced by a switch with motion detectors and the air-conditioning of the office spaces was also regulated.

The building is regularly maintained through daily operation and routine maintenance work as well as regular inspections of the equipment and systems. An energy audit [62] was carried out in 2014, which showed that the opaque façade elements had a $\mathrm{U}=0.75 \mathrm{~W} /\left(\mathrm{m}^{2} \mathrm{~K}\right)$, and the worse results were given for the glazed ground floor of the façade.

\section{Results and Discussion}

The applicability of the proposed methodological framework for the sustainable assessment of the renovation of an existing office building is supported here by the case study of a comprehensive renovation of the office building in the city of Maribor. Due to the location of the building in Europe, the general accessibility of the guidelines and special determination of the assessment system for office buildings, the BREEAM rating system was used for a sustainable evaluation of the renovation within the proposed framework. 


\subsection{Implementation of Methodological Framework Using BREEAM}

In our case study, the building owner wants to examine the possible strategies for renovating the existing building. An energy audit for the building is currently available [62]. When planning the desired level of renovation, the owner needs to follow instructions that are consistent with the objectives of sustainable construction projects. In addition, the owner would have to carry out energy and cost analyses for the planned renovation strategies and determine an overall rating of the building's level of sustainability and environmental impacts after renovation. In general, the methodological framework is used for this purpose. In the following steps, a sustainable evaluation and, in addition, an economic evaluation of the renovation solutions is carried out in the form of a CBA.

First of all, a project team must be set up to carry out the physical inspection of the building elements and to check the energy audit report already prepared. The project team must include a dedicated construction consultant (his own or one appointed by the owner) who is familiar with the content of the BREEAM rating system. On the basis of the data collected, the following measures are proposed: (a) renovation of the building envelope: façade (replacement of the thermal insulation and façade panels with a substructure, replacement of the glass façade walls on the ground floor), windows and doors, and the roof; (b) renovation of the interiors: ceilings (partially-non-existent); and (c) renovation of the active technical systems: heating and cooling (partly in meeting rooms). The renovation does not include the replacement of existing installation material.

In general, all these measures are energy and non-energy measures and together form the Baseline Scenario. An energy performance comparison is made for energy-related measures by combining data from the energy audit [62] and the current state of the building before renovation. The calculated saving of the specific energy consumption for heating was $127.74 \mathrm{~kW} \mathrm{~h} /\left(\mathrm{m}^{2} \mathrm{a}\right)(77.35 \%$ of the current

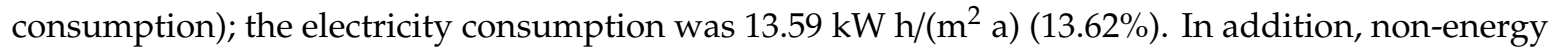
related measures, also known as functional improvement, contribute to raising the overall rating of sustainable building.

Furthermore, the target level 4 "Comprehensive Refurbishment" [40] was set and all proposed measures were accepted in Step 2. The evaluation of the renovation measures was carried out according to the selected BREEAM and the chosen assessment scheme "Refurbishment and Fit Out" and the technical manual International Non-Domestic Refurbishment 2015 [54]. Assuming that the owner would set the target rating benchmarks as "very good", this would require at least $55 \%$ of the total credits.

In Step 3, all impact categories that apply to the selected target rating are selected. The renovation assessment is carried out according to the chosen Technical Manual [54]. In principle, the standard refers to impact categories as "environmental sections" and the assessment criteria as "assessment issues". The chosen assessments scheme is used to provide a modular set of criteria related to the scope of the measures. The minimum requirements for the rating "very good" include the following mandatory assessment criteria: Mat 03-Responsible sourcing of materials, Wat 01-Water consumption, Wat 02-Water monitoring, and Ene 02-Energy monitoring. To achieve a better rating, the following assessment criteria were added: Man 01, Man 02, Man 03, Hea 01, Hea 02, Ene 01, Tra 01, Wst 01, Pol 03, Pol 05, and Inn. Table 3 gives an overview of the relevant criteria. However, the credits for Inn are only awarded if the renovation can achieve exceptional results for one or more specific criteria. In our case study, six credits were awarded for the Inn criteria. Taking all criteria into account, the possible total number of credits was 152 (see Table 2).

The final step, Step 4, provides a final decision based on two sets of assessments, namely the sustainable evaluation and a CBA economic evaluation of the proposed measures. 
Table 3. Impact categories, assessment criteria, and scoring of the renovation measures.

\begin{tabular}{|c|c|c|c|c|c|}
\hline \multicolumn{6}{|c|}{ BREEAM } \\
\hline \multicolumn{6}{|c|}{ Refurbishment and Fit-Out } \\
\hline Offices/Commercial Buildings & $\begin{array}{l}\text { Credits } \\
\text { Achieved }\end{array}$ & $\begin{array}{l}\text { Credits } \\
\text { Available }\end{array}$ & $\begin{array}{l}R \text { of Credits } \\
\text { Achieved, \% }\end{array}$ & $\begin{array}{l}\text { Category } \\
\text { Weights }\end{array}$ & $\begin{array}{l}\text { Category } \\
\text { Score }\end{array}$ \\
\hline Man-Management & 12 & 21 & 57.14 & 0.12 & 6.86 \\
\hline Man 01 Project brief and design & 4 & 4 & & & \\
\hline Man 02 Life cycle cost and service life planning & 4 & 4 & & & \\
\hline Man 03 Responsible construction practices & 4 & 6 & & & \\
\hline Hea-Health and wellbeing & 8 & 22 & 36.36 & 0.15 & 5.45 \\
\hline Hea 01 Visual comfort & 5 & 7 & & & \\
\hline Hea 02 Indoor air quality & 3 & 5 & & & \\
\hline Ene-Energy & 10 & 35 & 28.57 & 0.19 & 5.43 \\
\hline Ene 01 Reduction of energy use and carbon emiss. & 8 & 12 & & & \\
\hline Ene 02 Energy monitoring & 2 & 2 & & & \\
\hline Tra-Transport & 3 & 11 & 27.27 & 0.08 & 2.18 \\
\hline Tra 01 Sustainable transport solutions & 3 & 8 & & & \\
\hline Wat-Water & 6 & 9 & 66.67 & 0.06 & 4.00 \\
\hline Wat 01 Water consumption & 5 & 5 & & & \\
\hline Wat 02 Water monitoring & 1 & 1 & & & \\
\hline Mat-Materials & 3 & 13 & 23.08 & 0.13 & 2.88 \\
\hline Mat 03 Responsible sourcing of materials & 3 & 4 & & & \\
\hline Wst-Waste & 5 & 13 & 38.46 & 0.08 & 2.88 \\
\hline Wst 01 Project waste management & 5 & 6 & & & \\
\hline LEO—Land use and ecology & 0 & 4 & 0 & 0.10 & 0.00 \\
\hline Pol—Pollution & 3 & 14 & 21.43 & 0.10 & 2.14 \\
\hline $\begin{array}{l}\text { Pol 03-Flood risk management and reducing } \\
\text { surface water run-off }\end{array}$ & 2 & 5 & & & \\
\hline Pol 05—Reduction of noise pollution & 1 & 1 & & & \\
\hline Inn-Innovation & 6 & 10 & 60.00 & 0.10 & 6.00 \\
\hline Total (Baseline Scenario): & 56 & 152 & & 1.00 & 37.83 \\
\hline
\end{tabular}

\subsubsection{Evaluation for Sustainability}

The scoring of each criterion employs a standardized tool or calculator [54]. First, for the Baseline Scenario, the number of credits achieved within each impact category was determined for each measure. Then, the proportion $R$ of the achieved credits that corresponded to the category is calculated, which is multiplied by the category weights and results in the category score. The total score for the category was thus $37.83 \%$. Checking compliance with the minimum standards for the target rating "Very good" shows that the owner would only achieve two stars and the certificate "Pass" for the Baseline Scenario, so the total number of credits corresponded to only 56 (see Table 3).

To achieve a higher rating and certificate level, further measures (additional or new) were added to the Baseline Scenario, referred to as Scenario 1. The following measures were added: (a) wall painting according to the Volatile Organic Compound standards (VOCs); (b) external bicycle enclosure (fenced) with showers and toilets inside; and c) additional documentation (LCA analysis and waste pre-renovation audit). These measures were aimed at increasing the functionality of a building. Next, a reassessment included the provision of the higher values of the credits for the criteria Hea 02 (+1 credit), Tra 01 (+3 credits), Wst 01 (+1 credit), and Inn (+2 credits), and supplementary for Mat 01 (+4 credits). This improves the total score, which would be 67 credits for Scenario 1 and $47.10 \%$ for the category. This would be sufficient to achieve three stars and the certificate "Good". An overview of the credits achieved for both scenarios is shown in Figure 4. Credits by the Baseline Scenario are shown as "Achieved" (blue), while additional credits for Scenario 1 represent credits in "Could be achieved" (green). 


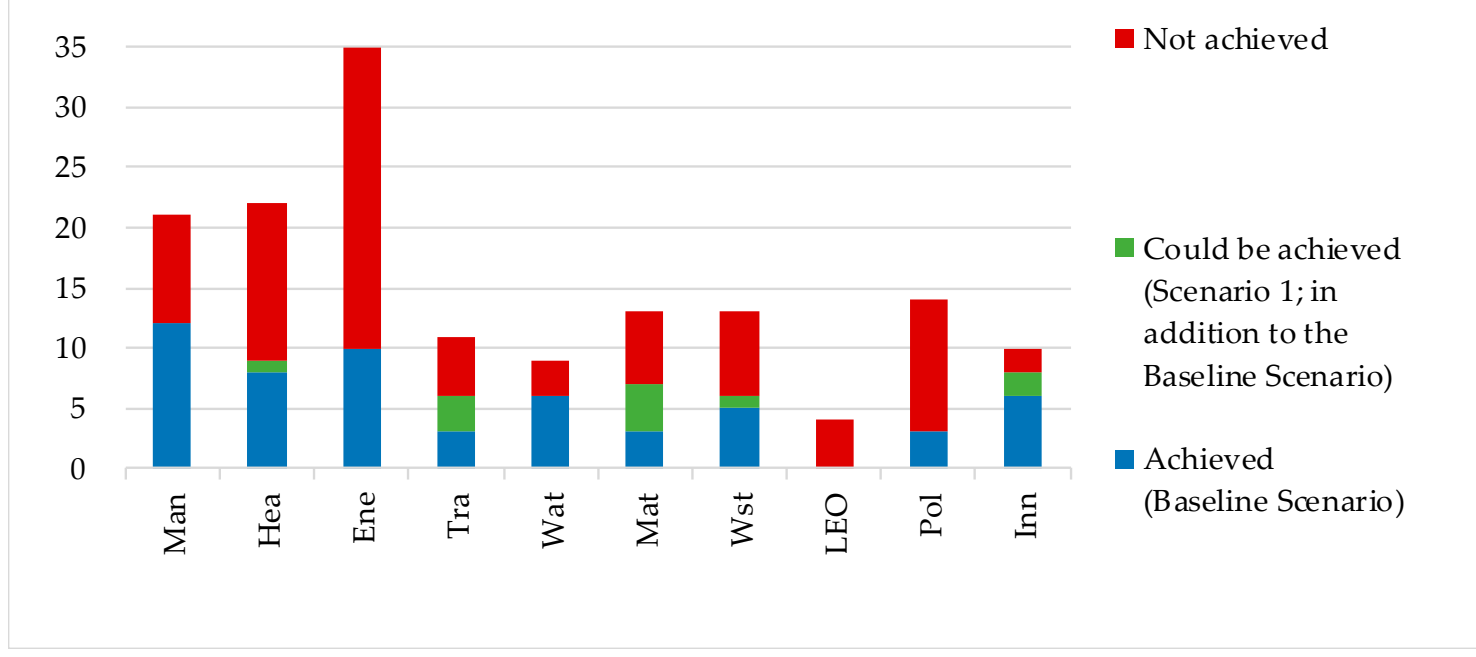

Figure 4. Scoring of the impact categories for the Baseline Scenario and Scenario 1.

\subsubsection{CBA Economic Evaluation}

The CBA was carried out in two phases for both scenarios. In the first phase, a financial analysis was carried out focusing on costs, while the second phase included an economic analysis, which the MPB also includes. In light of the multiple benefits, two additional scenarios were created, namely the Baseline Scenario with MPB, and Scenario 1 with MPB. The implemented CBA approach does not address the risks and uncertainties.

For both project scenarios, all necessary elements of measures were collected to calculate the impact on costs. In the first phase, the annual energy savings were analyzed and the monetary benefits from the reduced energy consumption were calculated to show the value and compare it with the investment expenditure. Furthermore, in the second phase, additional project benefits were also considered in the calculation of the net present value.

The following features were considered in the economic modeling:

1. Initial investment costs: These were taken from the energy audit data [62] recalculated to the present time [63] where the Baseline Scenario costs for (i) the preparation of the schematic design documentation, (ii) the construction and finishing works (including the costs for material, labor, equipment), and (iii) the implementation of organizational, so-called non-technical measures, all without VAT. The investments for the Baseline Scenario (Pass) amounted to $1.86 \mathrm{M€}$ or $289.26 € /\left(\mathrm{m}^{2} \mathrm{~A}_{\mathrm{NHF}}\right)$ and for Scenario 1 (Good) to $2.00 \mathrm{M} €$ or $310.95 € /\left(\mathrm{m}^{2} \mathrm{~A}_{\mathrm{NHF}}\right)$. Figure 5 shows the initial investment costs $\left(\right.$ in $€ / \mathrm{m}^{2}$ ) for the $A_{\mathrm{NHF}}$ for both scenarios.

2. Energy savings: These were calculated as energy savings [62] and evaluated as operating costs, assuming a unit cost of natural gas of $0.064 € /(\mathrm{kW} \mathrm{h})$ and electricity of $0.116 € /(\mathrm{kW} \mathrm{h})$ including taxes and charges [62]. The total annual savings amounted to $62,796.52 €$ or $9.75 € /\left(\mathrm{m}^{2}\right.$ a) $\left(\mathrm{A}_{\mathrm{NHF}}\right)$. The inflation rate for energy prices is generally calculated at $4 \% / \mathrm{a}$. Additional savings potential such as savings from the reduction of HVAC equipment and other potential savings that contribute to avoided operating costs were not taken into account.

3. The maintenance costs: These were considered as replacements for existing and worn out equipment and structures. Their calculation is based on the national rules on standards for the maintenance of apartment buildings and apartments [64]. The rules provide empirical data on maintenance costs for most building elements and HVAC systems, which represent a proportion (in \%) of the investment costs of a newly constructed element or system. In our case study, an average depreciation over the lifetime of the building was considered, namely $0.33 \%$ for the building envelop and $1.33 \%$ for HVAC systems. Equipment maintenance costs include the 
replacement costs for active technical systems according to their life expectancy [64]: radiator valves and pumps 10 a (years), ventilation, and recovery system 20 a (years). The replacement costs are thus $41,205 €$ in 2030 and $57,399 €$ in 2040 .

4. Residual value: This is the value of an asset at the end of its service life and indicates the value that the owner can expect to obtain if the asset is dispositioned. In our case study, the amount of residual value was calculated by taking into account the carrying amount of the asset. The residual value for the technical system components (with lifetime of 10 and 20 year) at the end of the lifetime period was $24,651 €$ and represents the difference between the investment value for the new installation of the new components and their value after five years (the study period of the building is then completed). While the lifetime for envelop components is more than 25 a (years) and the residual values for these measures are taken into account as the difference between the initial investment value and the value of the component at the end of the lifetime period, they amount to $777,442 €$.

5. Multiple project benefits (MPB): These were included in both scenarios as: (i) higher building value: various studies have shown that a certified green building has a positive impact on the building value after non-certified buildings of $4 \%$ to $21 \%$ [38] or $100-260 € / \mathrm{m}^{2}$ [38]. In our case study, the value of $150 € / \mathrm{m}^{2}$ was summarized and divided by the years of lifetime; and (ii) avoidance of Greenhouse Gas (GHG) emissions: increased energy production leads to a reduction in GHG emissions, so a reduction in $\mathrm{CO}_{2}$ per ton is considered annually. In the benefit calculations, the factors for specific $\mathrm{CO}_{2}$ emissions are summarized by Technical Guidelines [53] $(0.53 \mathrm{~kg} /(\mathrm{kW} \mathrm{h})$ for electricity and $0.20 \mathrm{~kg} /(\mathrm{kW} \mathrm{h})$ for energy from natural gas $)$, and the monetary value of the $\mathrm{CO}_{2}$ savings by study [38] was $10 € / \mathrm{t}$ a.

Assumptions of the economic calculation: The calculations focus on a period of 25 years, whereby the NPV method according to Equations (1) and (2), with a discount rate of the investment of $4 \%$ and an increase in energy costs of $4 \%$. Table 4 shows the starting points of the economic modeling.

The first phase of the CBA focuses on only the costs (i.e., the investment and the costs avoided during the building operation). The net present value is calculated considering the total initial investment and maintenance costs and the energy cost savings (Table 5). The second phase of the CBA additionally includes MPB, among which are a higher building value and an avoidance of GHG emissions (Table 5).

The results in Table 5 show that the net present value in the financial analysis was negative for both scenarios, which means that they are not cost-effective within 25 years. This is due to the investment expenditure, which includes not only energy saving measures, but also investments in the improved functionality of the building. However, by considering additional benefits, the net present value becomes positive. Regarding other additional benefits such as staff productivity could lead to an even higher cost-effectiveness of the project.

The value of the existing office building amounted to $683.14 € / \mathrm{m}^{2} \mathrm{~A}_{\mathrm{NHF}}$ and is derived from the model of mass real estate valuation, which is available on a public portal [65]. Adding the initial investment costs for renovation solutions (excluding MPB), the value of the building was $972.40 € / \mathrm{m}^{2}$ $\mathrm{A}_{\mathrm{NHF}}$ for the Baseline Scenario and $994.09 € / \mathrm{m}^{2} \mathrm{~A}_{\mathrm{NHF}}$ for Scenario 1. As a result, all the calculated values have to be compared in order to make the final decision to either renovate the building, or demolish it and build a replacement on the same location, or sell it and rebuild it on another location. In addition, consideration should be given to the characteristics of the real estate market, the characteristics of the location and spatial conditions, and the construction services in the area concerned. 
Building $6440 \mathrm{~m}^{2}\left(\mathrm{~A}_{\mathrm{NHF}}\right)$

- paints (by standard VOC)

- organizational measures

- circulation pumps

- hydraulic balancing of heating system

doors and glass facade

thermal insulation roof, ceiling

design documentation space for bikes and showers

hot water heat pump

- ventilation and recovery (meeting rooms)

radiator valves

windows

thermal insulation external wall

350

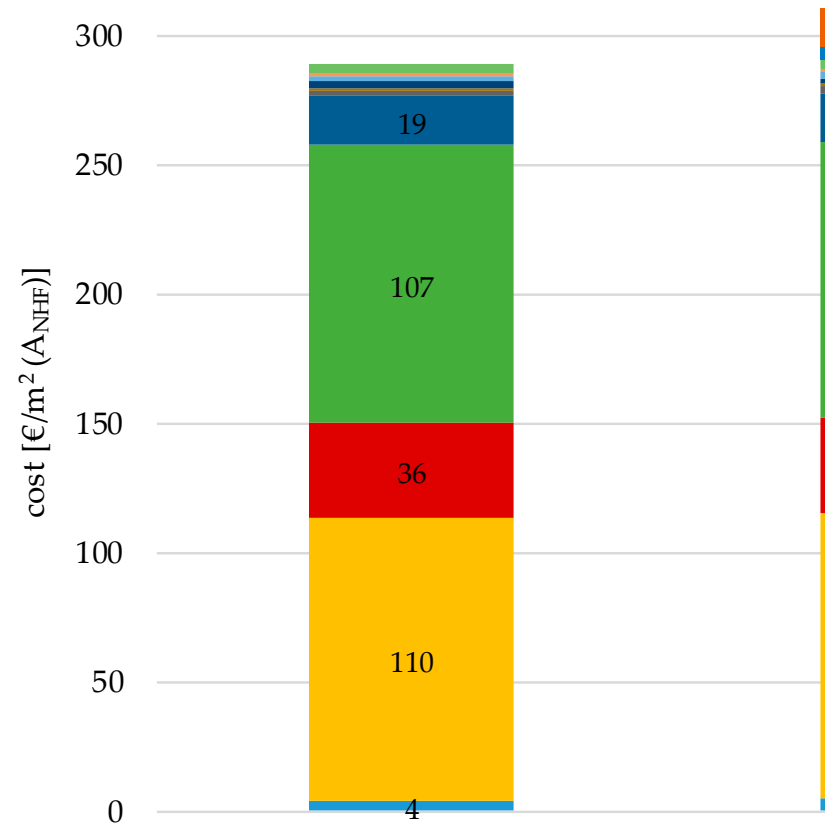

Baseline Scenario

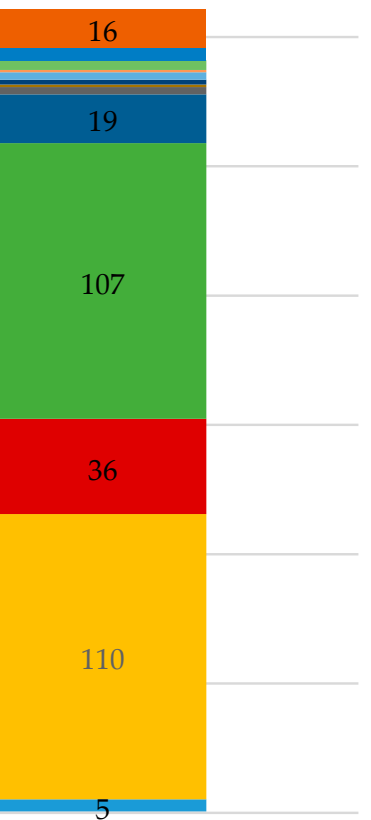

Scenario 1

Figure 5. Initial investment costs for both scenarios of sustainable renovation.

Table 4. Starting points of the economic modeling.

\begin{tabular}{ccc}
\hline Starting Points & Unit & Value \\
\hline Lifetime period, $t$ & Years & 25 \\
Discount rate of investment, $\mathrm{i}$ & $\%$ & 4 \\
Increment of the cost of energy & $\%$ & 4 \\
Maintenance costs for envelop measures & $\% / \mathrm{a}$ & 0.33 \\
Maintenance costs for technical systems & $\% / \mathrm{a}$ & 1.33 \\
Energy price, natural gas & $€ /(\mathrm{kW} \mathrm{h})$ & 0.064 \\
Energy price, electricity & $€ /(\mathrm{kW} \mathrm{h})$ & 0.116 \\
\hline
\end{tabular}


Table 5. Initial investment costs, maintenance costs, and energy savings during the first year and NPV.

\begin{tabular}{ccc}
\hline & Baseline Scenario & Scenario 1 \\
\hline Investment [€] & $1,862,808$ & $2,002,519$ \\
Maintenance costs [€] & 6622 & 6622 \\
Energy cost savings [€] & 62,797 & 62,797 \\
$\mathrm{NPV}_{0, \mathrm{f}}$-25 years [€] & $-205,264.52$ & $-344,975.72$ \\
$\mathrm{NPV}_{0, \mathrm{f}-25 \text { years }\left[€ / \mathrm{m}^{2}\right]}$ & -31.87 & -53.57 \\
$\mathrm{MPB}$ - at end of lifetime period & 966,000 & 966,000 \\
$\mathrm{MPB}-$ annually & 2109 & 2109 \\
$\mathrm{NPV}$ & $203,747.71$ & $64,036.51$ \\
$\mathrm{NPV}_{0, \mathrm{e}}-25$-25 years $\left[€ / \mathrm{m}^{2}\right]$ & 31.64 & 9.94 \\
\hline
\end{tabular}

It is generally expected that the green building rating system for the evaluation of sustainable construction projects will become a permanent practice in the future. Various reports on the green building rating system also show the continuous and global growth of certificates issued in recent years [13-16]. In this respect, an increase in sustainable appraisal for renovations of existing office buildings is expected. It is likely that more investment will be made in these buildings due to EU and long-term national strategies.

Furthermore, evaluating the degree of sustainability within the criteria set in any green building rating system is perceived as time consuming and requires a good knowledge of the principles and operation tools. Such an assessment usually falls within the scope of certified verifiers. However, the proposed new framework is intended to provide a comprehensive evaluation of proposed renovation solutions in a systematic and simple way to assist the owner in their decision-making. The formation of a project team including an expert with knowledge of the sustainability evaluation criteria provides a sufficiently high-quality basis for correct decisions and ensures that the principles of sustainable development are implemented. As a result, the owner receives (i) information on the level of certification of a sustainable building, and (ii) an estimate of the cost-effectiveness of the investment.

We assume, however, that a sustainable evaluation by the chosen green building rating system does not have to be carried out by a certified expert, as it is only an assessment of measures within certain assessment criteria and impact categories. On the basis of the results obtained (technical and economic), the owner can consider the possibilities of additional measures and recalculate their impact on the overall rating of the building's sustainability level.

\section{Conclusions}

The development of society and thus also the processes and activities in the AEC industry increasingly take into account the idea of sustainability. In the EU today, the goals of sustainable development are recognized as global, primarily strategic goals, and are implemented through legislation, policy documents, national strategies, and guidelines. In addition, various green building rating systems are used worldwide as benchmarks for the evaluation of sustainable construction projects.

So far, much research and evaluation has focused on the concept of sustainability thinking for the needs of public housing. It is expected that in the future, a major focus will be on office buildings, especially in the renovation of this type of building stock. It is therefore important that owners or their experts have a systematic and unified procedure in place from the early stages of a renovation project to identify the best designed renovation strategies. It is important that the procedure is relatively straightforward and serves as a decision-making tool to provide answers to the question of how to achieve a target rating of sustainable renovation solutions and cost-effectiveness. Therefore, the paper combines the most common features of green building rating systems and an upgrading of the sustainability rating with a cost-benefit analysis, and thus represents a novelty in decision-making support for the renovation of sustainable office buildings at an early stage. The main contribution lies in the developed methodological framework of procedures for sustainable office building renovation, which was designed in four steps. The framework has decision-making capabilities and provides 
a step-by-step assessment including a sustainable evaluation with the green building rating tool and an economic evaluation by means of CBA. The research is limited to the application of the LEED, BREEAM, and DGNB rating systems to the renovation of office buildings. The rating systems are presented in more detail, with the assessment scheme, the assessment system, the rating level, and the impact categories. The CBA and the basis of other project-based benefits are presented for the economic evaluation purposes. The applicability of the envisaged framework is implemented in the case study for a comprehensive renovation of an office building in the city of Maribor. The sustainable evaluation and economic valuation was carried out for two scenarios. For the sustainable assessment, the criteria according to BREEAM were introduced using the assessment scheme "Refurbishment and Fit-Out". The results showed that the implementation of the initially analyzed measures (Baseline Scenario) as well as the additionally designed measures (Scenario 1) could not provide the owner with the target rating. For the purposes of economic evaluation, the CBA shows that the investment is not financially justified if only the costs within the calculation period are taken into account, but compliance with the additional benefits leads to an economically viable investment.

The presented methodological framework is intended to be a valuable tool in the decision-making process with which an office building owner plans a renovation that follows the sustainability concept and is carried out without in-depth knowledge of the individual assessment criteria of selected rating tools. The proposed procedure can also be applied globally, using the most appropriate regional green building rating system and taking into account the regional characteristics of the real estate market. The paper may also be useful for different groups such as national and local authorities, users, planners, builders, owners, investors, etc. In addition, the intended decision-making procedure takes into account the owner's aspects, who sees the concept of sustainability as a way to keep the costs of maintenance and operation in their best interest. A building renovated in this way also has an impact on the well-being and productivity of the employees.

A recommendation for future work would be to study and analyze peer-to-peer comparisons of green building rating systems at the level of individual criteria within impact categories and to introduce other decision support methodologies such as multiple-criteria decision-making (MCDM), multiple-criteria decision analysis (MADM), and others. Furthermore, research could focus on the analysis of criteria for the sustainable renovation of infrastructure facilities and the integration of the BIM approach.

Author Contributions: Conceptualization, N.Š.; Methodology, N.Š.; Validation, N.Š., M.M., and M.K.; Formal analysis, N.Š., Resources, N.Š., M.M., and M.K.; Data curation, N.Š. and M.K., Writing—original draft preparation, N.Š.; Writing—review and editing, N.Š., M.M., and M.K.; Visualization, M.K. All authors have read and agreed to the published version of the manuscript.

Funding: This research received no external funding.

Conflicts of Interest: The authors declare no conflict of interest.

\section{References}

1. United Nations. Transforming Our World: The 2030 Agenda for Sustainable Development A/RES/70/1. 2015. Available online: https://sustainabledevelopment.un.org/content/documents/21252030\%20Agenda\%20for\% 20Sustainable\%20Development\%20web.pdf (accessed on 2 July 2020).

2. Directive 2002/91/EC of the European Parliament and of the Council of 16 December 2002 on the Energy Performance of Buildings. Available online: https://eur-lex.europa.eu/legal-content/EN/TXT/?uri=CELEX\% 3A32002L0091 (accessed on 15 May 2019).

3. Directive 2010/31/EU of the European Parliament and of the Council of 19 May 2010 on the Energy Performance of Buildings. Available online: https:/eur-lex.europa.eu/legal-content/EN/TXT/?qid=1534941584761\&uri= CELEX:32010L0031 (accessed on 15 May 2019).

4. World Green Building Council. World's Largest Collaborative Retrofit Project Launches to Cut Emissions from Buildings. 2016. Available online: https://www.worldgbc.org/news-media/world\%E2\%80\%99s-largestcollaborative-retrofit-project-launches-cut-emissions-buildings (accessed on 15 June 2019). 
5. The European Portal for Energy Efficiency In Buildings. Practical Approaches to the Building Renovation Challenge. 2016. Available online: http://www.buildup.eu/en/practices/publications/practical-approachesbuilding-renovation-challenge-0 (accessed on 18 June 2019).

6. European Commission. EASME-Executive Agency for SMEs. Available online: https://ec.europa.eu/easme/ en (accessed on 17 June 2019).

7. European Commission. Practical Approaches to the Building Renovation Challenge. Available online: https: //ec.europa.eu/easme/sites/easme-site/files/practical_approaches_to_the_buildings_renov_challenge.pdf (accessed on 23 June 2019).

8. European Commission. Horizon 2020, Secure, Clean and Efficient Energy. Available online: https: //ec.europa.eu/programmes/horizon2020/en/h2020-section/secure-clean-and-efficient-energy (accessed on 23 June 2019).

9. Ministry of Infrastructure; Ministry of Public Administration. Long-Term Strategy for Mobilising Investments in the Energy Renovation of Buildings (DSEP). Ljubljana, Slovenia, 2015. Available online: http: //www.energetika-portal.si/fileadmin/dokumenti/publikacije/dseps/dseps_final_okt2015.pdf (accessed on 15 May 2019). (In Slovene)

10. U.S. Green Building Council (USGBC), LEED. Available online: http://www.usgbc.org/leed (accessed on 24 June 2019).

11. Building Research Establishment Ltd., BREEAM. Available online: http://www.breeam.com/ (accessed on 24 June 2019).

12. German Sustainable Building Council, DGNB. Available online: https://www.dgnb.de/en/index.php (accessed on 24 June 2019).

13. Bernardi, E.; Carlucci, S.; Cornaro, C.; Bohne, R.A. An analysis of the most adopted rating systems for assessing the environmental impact of buildings. Sustainability 2017, 9, 1226. [CrossRef]

14. Kaur, H.; Garg, P. Urban sustainability assessment tools: A review. J. Clean. Product. 2019, 210, 146-158. [CrossRef]

15. BREEAM. Explore BREEAM. Available online: https://tools.breeam.com/projects/explore/index.jsp (accessed on 27 February 2020).

16. Statista. Cumulative Number of LEED Registrations in the U.S. from 2000 to 2019. Available online: https://www. statista.com/statistics/323383/leed-registered-projects-in-the-united-states/ (accessed on 27 February 2020).

17. European Commission. Building Sustainability Performance-Level(s). Available online: https://ec.europa. eu/environment/eussd/buildings.htm (accessed on 23 June 2019).

18. Yuanyuan Li, Y.; Chenb, X.; Wangb, X.; Xub, Y.; Chen, P. A review of studies on green building assessment methods by comparative analysis. Energy Build. 2017, 146, 152-159. [CrossRef]

19. Doan, D.T.; Ghaffarianhoseini, A.; Naismith, N.; Zhang, T.; Ghaffarianhoseini, A.; Tookey, J. A critical comparison of green building rating systems. Build. Environ. 2017, 123, 243-260. [CrossRef]

20. Cole, J.R.; Valdebenito, M.J. The importation of building environmental certification systems: International usages of BREEAM and LEED. Build. Res. Inf. 2013, 41, 662-676. [CrossRef]

21. Zeinal, H.A.; Huber, F. A comparative study of DGNB, LEED and BREEAM certificate system in urban sustainability. WIT Transact. Ecol. Environ. Sustain. City VII 2012, 155, 121-132. Available online: http://www.witpress.com/elibrary/wit-transactions-on-ecology-and-the-environment/155/23107 (accessed on 15 May 2019). [CrossRef]

22. Schwartz, Y.; Raslan, R. Variations in results of building energy simulation tools, and their impact on BREEAM and LEED ratings: A case study. Energy Build. 2013, 62, 350-359. [CrossRef]

23. Al Qahtany, A.; Rezgui, Y.; Li, H. A proposed model for sustainable urban planning development for environmentally friendly communities. Archit. Eng. Des. Manag. 2013, 9, 176-194. [CrossRef]

24. Carli, R.; Dotoli, M.; Pellegrino, R.; Ranieri, L. A Decision Making Technique to Optimize a Buildings' Stock Energy Efficiency. IEEE Transact. Syst. Man Cybern. Syst. 2017, 47, 794-807. [CrossRef]

25. Kaklauskas, A.; Zavadskas, E.K.; Raslanas, S. Multivariant design and multiple criteria analysis of building refurbishments. Energy Build. 2005, 37, 361-372. [CrossRef]

26. Ma, Z.J.; Cooper, P.; Daly, D.; Ledo, L. Existing building retrofits: Methodology and state-of-the-art. Energy Build. 2012, 55, 889-902. [CrossRef]

27. Juan, Y.; Gao, P.; Wang, J. A hybrid decision support system for sustainable office building renovation and energy performance improvement. Energy Build. 2010, 3, 290-297. [CrossRef] 
28. Rey, E. Office building retrofitting strategies: Multicriteria approach of an architectural and technical issue. Energy Build. 2004, 36, 367-372. [CrossRef]

29. Roulet, C.A.; Flourentzou, F.; Labben, H.H.; Santamouris, M.; Koronaki, I.; Dascalaki, E.; Richalet, V. ORME: A multicriteria rating methodology for buildings. Build. Environ. 2002, 37, 579-586. [CrossRef]

30. Chidiac, S.E.; Catania, E.J.C.; Morofsky, E.; Foo, S. A screening methodology for implementing cost effective energy retrofit measures in Canadian office buildings. Energy Build. 2011, 43, 614-620. [CrossRef]

31. Malatji, E.M.; Zhang, J.; Xia, X. A multiple objective optimisation model for building energy efficiency investment decision. Energy Build. 2013, 61, 81-87. [CrossRef]

32. Menassa, C.C. Evaluating sustainable retrofits in existing buildings under uncertainty. Energy Build. 2011, 43, 3576-3583. [CrossRef]

33. Mauro, G.M.; Hamdy, M.; Vanoli, G.P.; Bianco, N.; Hensen, J.L. A new methodology for investigating the cost-optimality of energy retrofitting a building category. Energy Build. 2015, 107, 456-478. [CrossRef]

34. Brown, N.W.; Malmqvist, T.; Bai, W.; Molinari, M. Sustainability assessment of renovation packages for increased energy efficiency for multi-family buildings in Sweden. Build. Environ. 2013, 61, 140-148. [CrossRef]

35. Allen, D.; Shonnaard, D. Sustainable Engineering Concept, Design and Case Studies; Prentice Hall: Upper Saddle River, NJ, USA, 2012.

36. Flourentzou, F.; Genre, J.L.; Roulet, C.A. TOBUS software-An interactive decision aid tool for building retrofit studies. Energy Build. 2002, 34, 193-202. [CrossRef]

37. Park, J.; Yoon, J.; Kim, K. Critical review of the material criteria of building sustainability assessment tools. Sustainability 2017, 9, 186. [CrossRef]

38. Bleyl, J.W.; Bareit, M.; Casas, A.M.; Chatterjee, S.; Coolen, J.; Hulshoff, A.; Lohse, R.; Mitchell, S.; Robertson, M.; Ürge-Vorsatz, D. Office building deep energy retrofit: Life cycle cost benefit analyses using cash flow analysis and multiple benefits on project level. Energy Effic. 2019, 12, 261-279. [CrossRef]

39. Lohse, R.; Staller, H.; Riel, M. The Economic Challenges of Deep Energy Renovation—Differences, Similarities, and Possible Solutions in Central Europe: Austria and Germany. Transactions 2016, 122, 69-87.

40. Shah, S. Sustainable Refurbishment; John Wiley \& Sons Ltd.: Oxford, UK, 2012.

41. Yudelson, J. Greening Existing Buildings; The McGraw-Hill Companies Inc.: New York, NY, USA, 2010.

42. European Commission. Comprehensive Study of Building Energy Renovation Activities and the Uptake of Nearly Zero-Energy Buildings in the EU, Final Report. Available online: https://ec.europa.eu/energy/sites/ ener/files/documents/1.final_report.pdf (accessed on 23 December 2019).

43. Šuman, N.; Žigart, M.; Premrov, M.; Žegarac Leskovar, V. Approach to refurbishment of timber preschool buildings with a view on energy and economic efficiency. J. Civil Eng. Manag. 2019, 25, 27-40. [CrossRef]

44. Directive 2009/28/ES of the European Parliament and of the Council of 23 April 2009 on the Promotion of the Use of Energy from Renewable Sources. Available online: https://eur-lex.europa.eu/legal-content/EN/ALL/ ?uri=CELEX\%3A32009L0028 (accessed on 15 May 2019).

45. Community Research and Development Information Service (CORDIS). Sustainability and Performance Assessment and Benchmarking of Buildings-SuPerBuildings. Available online: https://cordis.europa.eu/ project/rcn/93577/factsheet/en (accessed on 18 May 2019).

46. Community Research and Development Information Service (CORDIS). Open House. Available online: https://cordis.europa.eu/project/rcn/93875/factsheet/en (accessed on 18 June 2019).

47. BUILD UPON. Available online: http://buildupon.eu/ (accessed on 15 June 2019).

48. Ministry of Infrastructure. Annual Energy Balance of the Republic of Slovenia for 2019. Ljubljana, Slovenia, 2019. Available online: https:/www.energetika-portal.si/fileadmin/dokumenti/publikacije/ energetskabilanca/ebrs_2019.pdf (accessed on 22 November 2019). (In Slovene)

49. Energy Act. Official Gazette of the Republic of Slovenia No. 60/19 and 65/20. Available online: http: //www.pisrs.si/Pis.web/pregledPredpisa?id=ZAKO6665 (accessed on 15 June 2020).

50. Ministry of Infrastructure. Energy Concept of Slovenia (in Preparation). Available online: https://www. energetika-portal.si//dokumenti/strateski-razvojni-dokumenti/energetski-koncept-slovenije/ (accessed on 15 October 2019). (In Slovene)

51. Ministry of Infrastructure. Action Plan for Energy Efficiency by 2020. Ljubljana, Slovenia, 2017. Available online: https:/www.energetika-portal.si/fileadmin/dokumenti/publikacije/an_ure/an_ure_20172020_final.pdf (accessed on 15 June 2019). (In Slovene) 
52. Official Gazette of the Republic of Slovenia. Rules on efficient use of energy in buildings with a technical guideline. Off. Gaz. Repub. Slovenia No. 51/10, 61/17. Available online: http://www.pisrs.si/Pis.web/ pregledPredpisa?id=PRAV10043 (accessed on 15 June 2020).

53. Ministry of the Environment and Spatial Planning. Technical Guidelines TSG-1-004:2010 Efficient Use of Energy. Ljubljana, Slovenia, 2010. Available online: http://www.mop.gov.si/fileadmin/mop. gov.si/pageuploads/zakonodaja/graditev_objektov/TSG_01_004_2010_ure.pdf (accessed on 15 June 2019). (In Slovene)

54. Bre Global Ltd. BREEAM International Non-Domestic Refurbishment 2015, Non-domestic buildings, Technical Manual SD225 1.4. UK. 2017. Available online: https://www.breeam.com/internationalRFO2015/ \#resources/output/rfrb_pdf_screen/sd225_rfo_int_2015_scr.pdf (accessed on 15 June 2019).

55. HQE. Discover and join HQE ${ }^{\mathrm{TM}}$. Available online: https://www.behqe.com/\# (accessed on 4 July 2020).

56. USGBC. LEED v4.1 Operation and Maintenance. Getting Started Guide for Beta Participants. 2019. Available online: https://www.usgbc.org/leed/rating-systems/existing-buildings (accessed on 4 July 2020).

57. CASBEE. Comprehensive Assessment System for Built Environment Efficiency. Available online: http: //www.ibec.or.jp/CASBEE/english/ (accessed on 4 July 2020).

58. NZGBC Green Star. Available online: https://www.nzgbc.org.nz/GreenStar (accessed on 4 July 2020).

59. DGNB. The DGNB System for Existing Buildings and Renovation. Available online: https://www.dgnbsystem.de/en/buildings/renovation-and-existing-buildings/ (accessed on 4 July 2020).

60. Gowri, K. Green building rating systems: An overview. ASHRAE J. 2004, 46, 56-59.

61. Risholt, B.; Time, B.; Hestnes, A.G. Sustainability assessment of nearly zero energy renovation of dwellings based on energy, economy and home quality indicators. Energy Build. 2013, 60, 217-224. [CrossRef]

62. Marinič, M. Defining the Parameters of Sustainable Refurbishment of Existing Office Buildings. Master's Thesis, University of Maribor, Faculty of Civil Engineering, Transportation Engineering and Architecture, Maribor, Slovenia, 2016. (In Slovene)

63. Chamber of Construction and Building Materials Industry of Slovenia. Indeksi za Obračun Razlike v Ceni Gradbenih Storitev; Chamber of Commerce and Industry of Slovenia: Ljubljana, Slovenia, December 2019.

64. Official Gazette of the Republic of Slovenia. Rules on Standards for the Maintenance of Apartment Buildings and Apartments. Off. Gaz. Repub. Slovenia No. 20/04,18/11. Available online: http://www.pisrs.si/Pis.web/ pregledPredpisa?id=PRAV5263 (accessed on 15 June 2020).

65. Ministry of the Environment and Spatial Planning. The Surveying and Mapping Authority of the Republic of Slovenia. Portal Prostor. 2019. Available online: http://www.e-prostor.gov.si/ (accessed on 15 August 2019). 